\title{
Insulin-Like Growth Factor II (IGF-II) Is More Potent Than IGF-I in Stimulating Cortisol Secretion from Cultured Bovine Adrenocortical Cells: Interaction with the IGF-I Receptor and IGF-Binding Proteins
}

\author{
MATTHIAS M. WEBER, PIA SIMMLER, CHRISTIAN FOTTNER, \\ AND DIETER ENGELHARDT \\ Medical Department II, Laboratory of Endocrine Research, Klinikum Grosshadern, \\ University of Munich, Munich, Germany
}

\begin{abstract}
Although the stimulating effect of insulin-like growth factor I (IGF-I) on adrenal steroidogenesis has been well established, the role of IGF-II in the adult adrenal gland remains unknown. We, therefore, investigated the effect of recombinant human IGF-II on cortisol and cAMP synthesis from adult bovine adrenocortical cells. IGF-II, time and dose dependently, stimulated basal cortisol secretion maximally 3 -fold. In combination with ACTH, IGF-II (13 nM) synergistically increased cortisol secretion from 18-fold $\left(10^{-8} \mathrm{M}\right.$ ACTH) to 28 -fold of untreated control levels. In contrast, IGF-I at equimolar concentrations did not show an effect on basal cortisol secretion, and in combination with ACTH elicited a significant weaker stimulatory effect than IGF-II (22-fold increase). The synergistic effect of IGF-II on ACTH-promoted cortisol secretion was paralleled by accumulation of cAMP in the culture medium. Although both IGF receptors are present in adult bovine adrenocortical cells, the effect of IGF-II seems to be mediated through interaction with the IGF-I receptor, as $\left\lceil\right.$ Arg $\left.^{54.55}\right]$ IGF-II, which only binds to the IGF-I receptor, was equipotent to native IGF-II, whereas [Leu $\left.{ }^{27}\right] \mathrm{IGF}-\mathrm{II}$, which preferentially binds to the type II IGF receptor, did not show any effect. By Western ligand blotting, four different molecular forms of IGF-binding
\end{abstract}

proteins (IGFBPs) were identified in conditioned medium of bovine adrenocortical cells with apparent molecular masses of $39-44,34,29$, and 24 kilodaltons. ACTH treatment increased the abundance of all binding proteins, on the average, 2.3-fold, except for the $29-\mathrm{kDa}$ band, which was predominantly induced 6.8 fold. Additionally, [des $\left.{ }^{1-3}\right]$ IGFI, a truncated IGF variant that exhibits only minimal binding to IGFBPs, was significant more potent than IGF-I and elicited the same maximum stimulatory effect on cortisol secretion as IGF-II and $\left[\operatorname{des}^{1-6}\right]$ IGF-II.

In conclusion, these results demonstrate that 1) IGF-II stimulates basal as well as ACI'H-induced cortisol secretion from bovine adrenocortical cells more potently than IGF-I; 2) this effect is mediated through interaction of IGF-II with the IGF-I receptor; 3 ) bovine adrenocortical cells synthesize various IGFBPs that are induced differentially by ACTH; and 4) IGFBPs apparently play a modulatory role in IGF-induced stimulation of adrenal sternidngenesis. Therefore, bovine adult adrenocortical cells provide a useful tissue culture model in which the interactions among locally produced IGFs, IGFBPs, and the IGF-I receptor can be evaluated. (Endocrinology 136: 37143720 , 1995)
$\mathrm{T}$ HE INSULIN-LIKE growth factors (IGF-I and IGF-II) are polypeptides, structurally related to proinsulin, that have been implicated in the hormonal regulation of growth and differentiation. IGF-I mediates the growth-promoting effects of GH in postnatal life, whereas IGF-II seems to be involved in the regulation of fetal growth. IGFs show mitogenic and differentiation-promoting activities in a variety of tissues in which they are produced locally and presumably act in a paracrine/autocrine manner (1-4). Both ligands interact with specific cell surface receptors, to which they bind with differing affinities. The type I IGF receptor is a heterotetramer transmembrane receptor, structurally related to the insulin receptor. It contains an intracellular tyrosine $\mathrm{ki}-$ nase domain and binds with high affinity to IGF-I and with only slightly weaker activity to IGF-II. The structurally distinct type II IGF receptor is identical to the cation-independent mannose-6-phosphate receptor (IGF-II/M6P receptor) and preferentially binds IGF-II with high affinity (5). Al-

Received March 6, 1995.

Address all correspondence and requests for reprints to: Dr. med. Matthias M. Weber, Medizinische Klinik II, Klinikum Großhadern, Marchioninistraße 15, 81377 München, Germany. though most effects of IGF-I and IGF-II are mediated through interaction of the ligands with the type I IGF receptor, the role of the IGF-II/M6P receptor in IGF signaling remains controversial $(6,7)$. Furthermore, the IGFs bind to a variety of IGF-binding proteins (IGFBPs) that are present in many tissues and body fluids and take part in the regulation of IGF action $(8,9)$.

There are accumulating data that IGFs play an important role in the regulation of growth and differentiation of the adrenal gland. Previous studies in several species have demonstrated the presence of IGF-I/II messenger RNA (mRNA) and peptide $(10-13)$ as well as IGF receptors in the adrenal gland (14-18). Furthermore, IGFs elicit mitogenic and differentiating effects in human adrenal cells in vitro (19-22). In bovine adrenocortical cells, IGF-I potentiates ACTH-induced cortisol secretion, upregulates $\mathrm{ACTH}$ receptors, and increases the $\mathrm{mRNA}$ abundance of various steroidogenic enzymes $(15,23-26)$. In the rat, however, an inhibitory role of IGF-I on steroid biosynthesis has been described (27), and IGF-II, but not IGF-I, in combination with insulin is mitogenic for fetal adrenal cells (28).

So far, all effects of IGF in adult adrenal cells have been attributed to IGF-I, whereas IGF-II is assumed to modulate 
fetal adrenal cell growth and differentiation. In the human fetal adrenal gland, IGF-II expression is high and up-regulated by ACTH (19), IGF-II enhances the steroidogenic response to ACTI I (20), and both IGFs stimulate fetal adrenal cell proliferation (19). Increased IGF-II mRNA levels were found in human adrenocortical tumors (29).

As the role of IGF-II in the regulation of the adult adrenocortical cell has not been investigated so far, we evaluated the effect of IGF-II on the basal and ACTH-stimulated steroidogenic responses of cultured bovine adrenocortical cells. As we have previously shown, these cells are responsive to IGF-I (26) and express both types of IGF receptors, with the IGF-II/M6P receptor being twice as abundant as the IGF-I receptor (18).

In the present study, we demonstrate that in bovine adrenocortical cells, IGF-II has a stronger stimulatory effect on cortisol secretion than IGF-I. By incubation experiments with mutant IGF ligands, we show that the effect of IGF-II is mediated through interaction with the IGF-I receptor and that the different potencies of IGF-I and IGF-II may be due to interaction of the ligands with IGFBPs. At least four different forms of IGFBPs are secreted by bovine adrenocortical cells, and their abundance is up-regulated by ACTH.

\section{Materials and Methods}

\section{Materials}

Recombinant human IGF-I and IGF-II were purchased from Boehringer (Mannheim, Germany); mutant recombinant [des ${ }^{1-3}$ IIGF-I and [des ${ }^{1-6}$ |IGF-II were obtained from GroPep (Adelaide, Australia). [Leu ${ }^{27}$ IIGF-II and $\left[\mathrm{Arg}^{54,55}\right.$ ]IGF-II, mutant recombinant human IGF-II analogs, were kindly provided by Daiichi Pharmaceutical Co. (Tokyo, Japan). (3-[125]iodotyrosyl)IGF-I and IGF-II (human recombinant; SA, $2000 \mathrm{Ci} / \mathrm{mmol}$ ) were purchased from Amersham Buchler and CoKG (Braunschweig, Germany), and $\left[{ }^{125} \mathrm{I}\right]$ cortisol was obtained from Sorin Biomedica (Braunschweig, Germany).

\section{Cell preparation and culture conditions}

Monolayer cell cultures of adult bovine adrenocortical cells were prepared as previously described (30). In brief, bovine adrenocortical tissue was enzymatically dispersed with $1 \%$ collagenase II and $0.075 \%$ deoxyribonuclease I ( $75 \mathrm{~min}$ at $37 \mathrm{C})$, filtered $(100 \mu \mathrm{m})$, and centrifuged

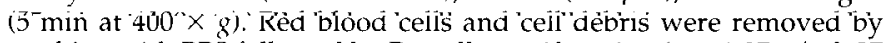
washing with PBS followed by Percoll centrifugation $(\rho=1.07 \mathrm{~g} / \mathrm{ml} ; 37$ C; Pharmacia, Uppsala, Sweden) for $10 \mathrm{~min}$ at $730 \times \mathrm{g}$. The band containing adrenocortical cells was resuspended in cell culture medium Imedium 199 containing $10 \%$ fetal calf serum, 5\% horse serum, L-glutamine $(292 \mu \mathrm{g} / \mathrm{ml})$, gentamycin $(52 \mu \mathrm{g} / \mathrm{ml})$, and amphotericin B $(0.5$ $\mu \mathrm{g} / \mathrm{ml})]$ and adrenocortical cells were grown in monolayers at $37 \mathrm{C}$ in a humidified atmosphere with $95 \%$ air-5\% $\mathrm{CO}_{2}$ for 2 days in $22-\mathrm{mm}$ multiwell plates. Twenty-four hours before the experiments, the medium was exchanged to serum-free medium Imedium 199 containing l-glutamine $(292 \mu \mathrm{g} / \mathrm{ml})$, gentamycin $(52 \mu \mathrm{g} / \mathrm{ml})$, and amphotericin B $(0,5 \mu \mathrm{g} / \mathrm{ml})]$. At confluency, cell density was $3.28 \pm 0.5 \times 10^{5}$ cells $/$ well, and cell viability was greater than $92 \%$, as confirmed by trypan blue exclusion after $96 \mathrm{~h}$ of incubation.

\section{Experimental procedure}

Bovine adrenocorlical cells $\left(1-3 \times 10^{5}\right.$ cells/well) were incubated with $1 \mathrm{ml}$ serum-free medium with or without ACTH $\left(10^{8} \mathrm{M}\right)$ and IGFs at the indicated concentrations for up to $96 \mathrm{~h}$. At the time points indicated, medium was aspirated and stored at $-30 \mathrm{C}$ for further analysis. At the end of each experiment, cell number was measured with a Coulter counter (Coulter Electronics, Hialeah, FL). Cortisol secreted into the medium was determined by specific RIA, as previously described (31). The standard curve demonstrated an $\mathrm{ED}_{20}$ of $500 \mathrm{ng} / \mathrm{ml}$ and an $\mathrm{ED}_{80}$ of $5 \mathrm{ng} / \mathrm{ml}$. All samples were diluted to fall on the linear part of the curve between these two values. The intra- and interassay coefficients of variation of this assay were less than $10 \%$. The amount of cAMP in the medium was measured by the $\left[{ }^{125} I\right]$ CAMP assay system from Amersham (Braunschweig, Germany). Assays were performed in duplicate, and all experiments were repeated at least six times with independent cell preparations. Treatment with ACTH induced a dose-dependent increase in cortisol secretion, with a half-maximal stimulation at $10^{8} \mathrm{M}$ ACTH.

\section{Western ligand blotting}

Bovine adrenal cells were incubated for $48 \mathrm{~h}$ with or without ACTH $\left(10^{-8} \mathrm{M}\right)$ under serum-free conditions. The medium corresponding to $3 \times 10^{6}$ cells was harvested and concentrated, and samples were separated by $12 \%$ sodium dodecyl sulfate-polyacrylamide gel electrophoresis under nonreducing conditions in a Laemmli buffer system. Proteins were electrotransblotted onto nylon membranes (Imobilon, Milipore, Munich, Germany). The IGFBPs were identified by autoradiography after overnight incubation of the filters with ${ }^{125}$ Ilabeled IGF-I or IGF-II at $4 \mathrm{C}$. The relative amount of each band was quantified by cutting the corresponding bands on the membrane and counting in a $\gamma$-counter.

\section{Statistics}

Data are depicted as the mean $\pm \mathrm{SEM}$, and differences between treatment groups were assessed by nonpaired $t$ testing.

\section{Results}

\section{IGF-II action in adult bovine adrenocortical cells}

In time-course experiments, adult bovine adrenocortical cells were treated with IGF-I or IGF-II (13 nM) with or without the addition of ACTH $\left(10^{-8} \mathrm{M}\right)$ for up to $48 \mathrm{~h}$ (Fig. 1). The addition of IGF-I alone (13 $\mathrm{nm}$ ) led to a moderate increase in basal cortisol secretion, which was significant after $48 \mathrm{~h}$ (2.4fold of control value; $P<0.05)$. In contrast, IGF-II (13 nм) stimulated basal cortisol secretion significantly after $12 \mathrm{~h}(P$ $<0.01$ ), with a 3.3-fold increase after an incubation time of

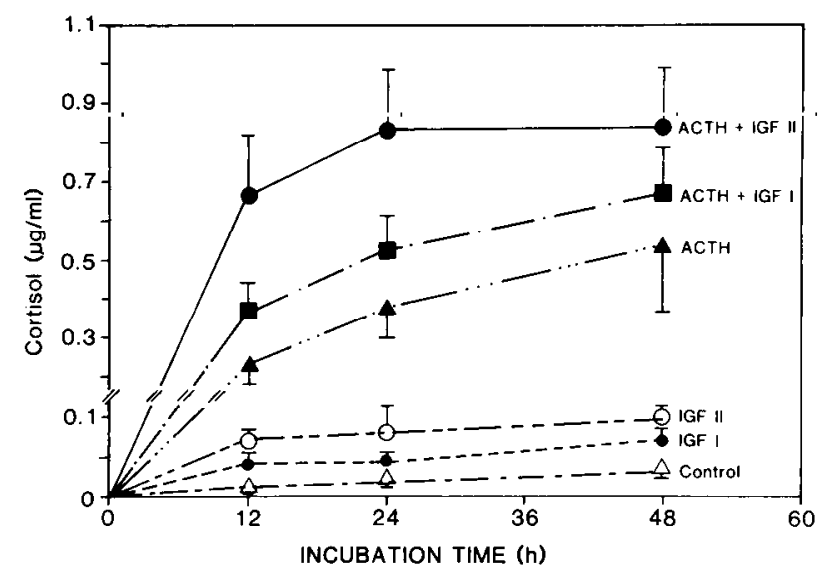

FIG. 1. Time course of IGF action on basal and ACTH-stimulated cortisol secretion in primary bovine adrenocortical cells. Cells $(1 \times$ $10^{5}$ ) were incubated in multiwell plates for $48 \mathrm{~h}$ in the presence of ACTH $\left(10^{8} \mathrm{M}\right)$, IGF-I, or IGF-II ( $\left.13 \mathrm{nM}\right)$. At each time point, medium was aspirated and assayed for cortisol. Each point represents six wells (mean \pm SEM). Data are representative of a single experiment performed independently at least six times. 
$48 \mathrm{~h}$. The stimulatory effect of IGF-II on cortisol secretion was stronger than the effect of IGF-I at all time points tested. As expected, the addition of ACTH $\left(10^{-8} \mathbf{M}\right)$ led to a marked maximal 19-fold increase in basal cortisol secretion after 48 h. IGF-II (13 nM) in combination with ACTH $\left(10^{-8} \mathrm{M}\right)$ showed a synergistic stimulatory effect on cortisol secretion by primary bovine adrenocortical cells, with a 29 -fold increase in cortisol levels after $48 \mathrm{~h}$. A significant stimulatory effect of IGF-II on ACTH-induced cortisol secretion was observed after $12 \mathrm{~h}$ of incubation (3-fold increase in ACTH-induced cortisol levels; $P<0.02$ ), and maximum cortisol levels were reached after $24 \mathrm{~h}$. In contrast, IGF-I in the same concentration was significantly less effective than IGF-II at enhancing ACTH-stimulated cortisol secretion (22-fold increase), and maximum levels of cortisol were reached only after $48 \mathrm{~h}$ of incubation.

The stimulatory effect of IGFs on basal as well as ACTHinduced cortisol secretion was paralleled by an increase in the accumulation of CAMP in the supernatant (Fig. 2). As expected, ACTII $\left(10^{-8} \mathrm{M}\right)$ was a potent stimulator of CAMP levels in the medium, with an increase from 2.4 to 29 $\mathrm{pmol} / \mathrm{ml}$ after an incubation period of $48 \mathrm{~h}$. Maximal levels of cAMP ( $49.3 \mathrm{pmol} / \mathrm{ml})$ were achieved with a combination of ACTH and IGF-II (3, 2 nM), whereas the combination of ACTH and IGF-I was significantly less potent $(39.6 \mathrm{pmol} /$ $\mathrm{ml}$ ). Treatment with IGF-II alone caused only a slight increase in CAMP and cortisol levels, and IGF-I alone had no effect. No mitogenic effect of either ligand on cell number was observed (data not shown).

Dose-response experiments with IGF-I and IGF-II in combination with ACTH showed that both ligands at very high concentrations (26-52 nM) maximally stimulated ACTH-induced cortisol secretion more than 3-fold (Fig. 3). Additionally, an equimolar combination of both IGFs at high doses did not elicit a further stimulatory effect. However, at low concentrations (0.4-0.8 nM), IGF-I did not show any significant stimulatory effect on cortisol secretion, whereas IGF-II produced half-maximal stimulation $(P<0.005)$. In contrast to

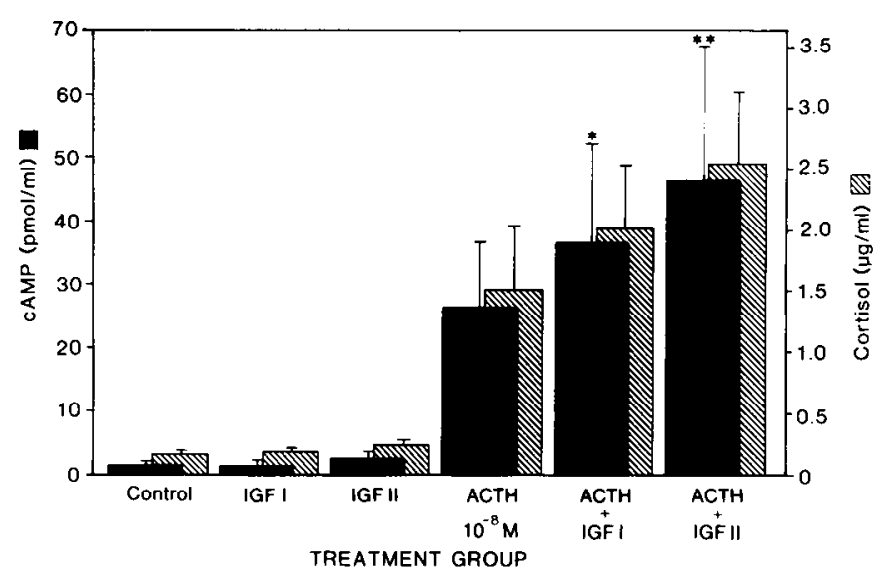

FIG. 2. Effects of ACTH and IGFs on cAMP and cortisol production in primary bovine adrenocortical cells. Cells $\left(3 \times 10^{5}\right)$ were incubated in multiwell plates for $48 \mathrm{~h}$ in the presence of $\Delta \mathrm{CTH}\left\langle 10^{-8} \mathrm{M}\right\rangle, \mathrm{IGF}-\mathrm{I}$, or IGF-II ( $3.2 \mathrm{nM}$ ). After incubation for $48 \mathrm{~h}$, medium was aspirated,

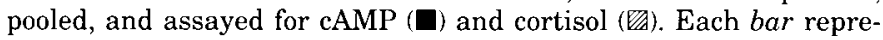
sents pooled samples of three independently performed experiments (mean \pm SEM). ${ }^{*}, P<0.05 ; * *, P<0.01$ (vs. ACTH group).

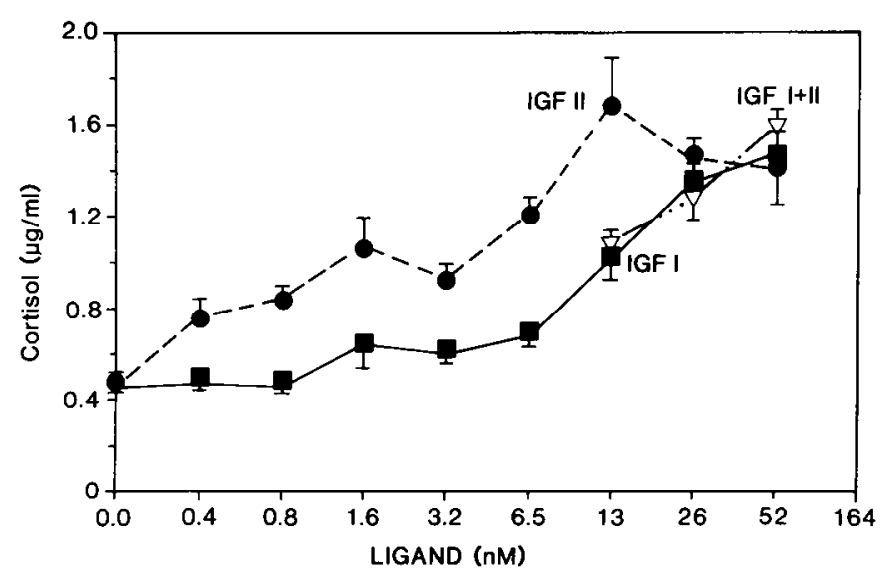

FIG. 3. Dose response of effect of IGF on ACTH-induced cortisol secretion in primary bovine adrenocortical cells. Cells $\left(2 \times 10^{5}\right)$ were incubated in multiwell plates in the presence of ACTH $\left(10^{-8} \mathrm{M}\right)$ and the indicated concentrations of IGF-I or IGF-II. After incubation for $36 \mathrm{~h}$, medium was aspirated and assayed for cortisol. Each point represents at least six wells (mean \pm SEM). Data are representative of four separate experiments.

IGF-II, the stimulatory effect of IGF-I was only significant for doses greater than $0.8 \mathrm{~nm}(P<0.01)$. The mean IGF concentrations required for a half-maximal stimulation of $\mathrm{ACTH}$ induced cortisol secretion $\left(\mathrm{ED}_{50}\right)$ in four separate experiments were 10 and $0.9 \mathrm{~nm}$ for IGF-I and IGF-II, respectively. Similar differences in the potencies of IGF-I and IGF-II were observed in dose-response experiments without ACTH (data not shown).

\section{Action of mutant IGF ligands on cortisol secretion}

To investigate the role of the IGF-I and the IGF-II/M6P receptor in mediating the effect of IGF-II in our cell system, two different mutant IGF-II ligands were used (32). [Leu ${ }^{27}$ ]IGF-II, containing a leucine substitution for tyrosine at amino acid position 27, exhibits high affinity $\left(K_{\mathrm{ct}}=0.05\right.$ $\mathrm{nM})$ for the type II IGF receptor but only low affinity $\left(\mathrm{K}_{\mathrm{d}}=\right.$ $66 \mathrm{nM}$ ) for the type I IGF receptor. In contrast, [ $\left.\operatorname{Arg}^{54,55}\right]$ IGFII, containing an arginine substitution for alanine-54 and leucine-55, displays a high affinity $\left(\mathrm{K}_{\mathrm{d}}=0.4 \mathrm{nM}\right)$ for the IGF-I receptor and no binding to the IGF-II/M6P receptor (32). [Leu ${ }^{27}$ ]IGF-II ( $3.2 \mathrm{nM}$ ) failed to stimulate ACTH-induced cortisol secretion in primary bovine adrenocortical cells despite the presence of IGF-II/M6P receptors in these cells (18). However, [Arg $\left.{ }^{54,55}\right]$ IGF-II, which binds to the IGF-I receptor, but not to the IGF-II/M6P receptor, stimulated cortisol secretion in bovine adrenal cells to a similar extent as equimolar concentrations of native IGF-II (Fig. 4). This confirms that the effect of IGF-II on cortisol synthesis in bovine adrenocortical cells is mediated through interaction of the IGF ligands with the IGF-I and not with the IGF-II/M6P receptor. Similar data were obtained when the cells were incubated with mutant ligands without the addition of ACTH (data not shown).

To elucidate a possible modulatory role of IGFBPs on the bioactivity of $\mathrm{iGF}-1$ and $\mathrm{iGF}-1 \mathrm{l}$ in our celì system, mutant $\mathrm{IGF}$ ligands with reduced affinities for IGFBPs were used (Fig. 5). [des ${ }^{1-3}$ ]IGF-I and [des ${ }^{1-6}$ ]IGF-II are truncated IGF variants lacking the first three and six $\mathrm{N}$-terminal amino acids, 


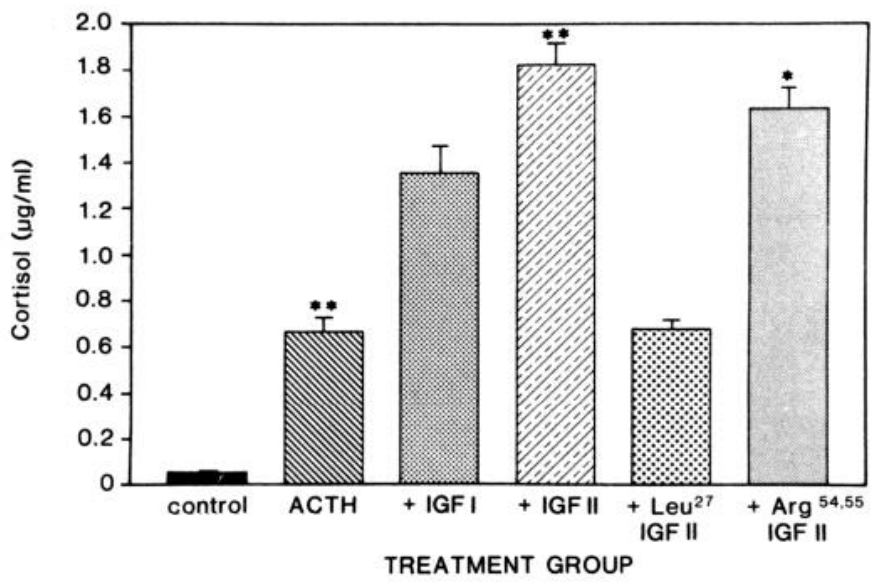

FIG. 4. Effects of mutant IGF-II ligands with altered binding to the IGF-I receptor on cortisol secretion in primary bovine adrenocortical cells. Cells $\left(2 \times 10^{5}\right)$ were incubated in multiwell plates in the presence of ACTH $\left(10^{-8} \mathrm{M}\right)$ and mutant or native IGF ligands (3.2 nM). After incubation for $48 \mathrm{~h}$, medium was aspirated and assayed for cortisol. Each bar represents 11 wells (mean $\pm \mathrm{SEM}$ ). *, $P<0.05$; **, $P<0.01$ ( $v s$. IGF-I group). Data are representative of a single experiment performed independently at least four times.

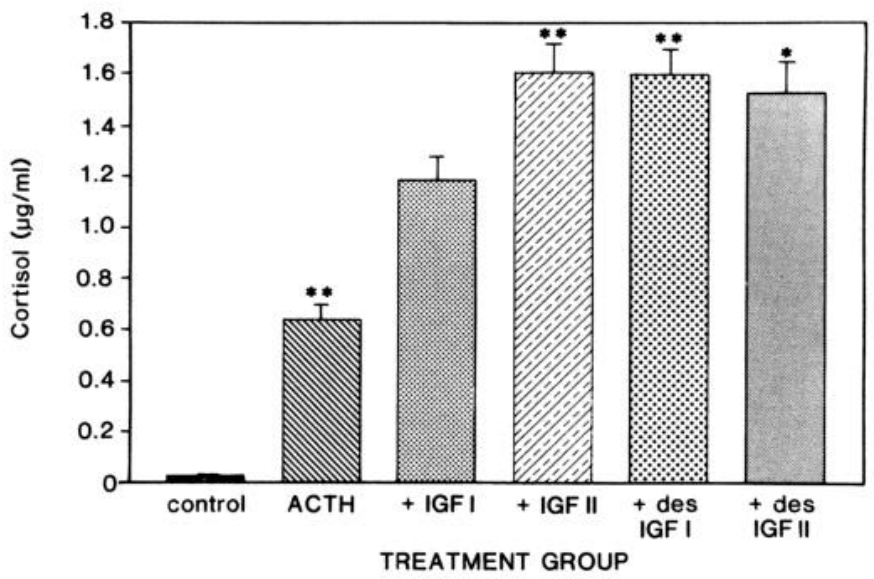

FIG. 5. Effects of mutant IGF ligands with decreased binding to IGFBPs on cortisol secretion in primary bovine adrenocortical cells. Cells $\left(2 \times 10^{5}\right)$ were incubated in multiwell plates in the presence of ACTH $\left(10^{-8} \mathrm{M}\right)$ and mutant or native IGF ligands (3.2 nM). After incubation for $48 \mathrm{~h}$, medium was aspirated and assayed for cortisol. Each bar represents at least 16 wells (mean \pm SEM). ${ }^{*}, P<0.05$; **, $P<0.01$ (vs. IGF-I group). Data are representative of five separate experiments.

respectively. Both show substantially decreased binding to IGFBPs whereas their affinities for the IGF receptors remain unaltered ([des $\left.{ }^{1-3}\right]$ IGF-I) or are slightly reduced $\left(\operatorname{des}\left[{ }^{1-6}\right]\right.$ IGF-II) (33). When ACTH-primed cells were treated with [des ${ }^{1-3}$ ]IGF-I ( $3.2 \mathrm{~nm}$ ) instead of native IGF-I, a significantly stronger stimulatory effect on ACTH-induced cortisol secretion was observed (2.2- vs. 3-fold increase in ACTH-stimulated control value; $P<0.02$ ). In contrast, [des ${ }^{1-6}$ ]IGF-II (3.2 nM) stimulated ACTH-induced cortisol secretion to a similar extent as native IGF-II and [des $\left.{ }^{1-3}\right]$ IGF-I. The fact that [des ${ }^{1-3}$ ]IGF-I was equipotent to IGF-II points to a modulatory role of IGFBPs in the regulation of IGF-stimulated cortisol secretion in bovine adrenal cells.

\section{Secretion of IGFBPs by bovine adrenocortical cells}

To identify IGFBPs synthesized by adult bovine adrenocortical cells, ligand blotting of cell-conditioned medium was performed with [ ${ }^{125}$ I]IGF-I and [ ${ }^{125}$ I]IGF-II. As shown in Fig. 6 , the medium of untreated control cells contains at least four specific bands, with a doublet of 39-44 $\mathrm{kDa}$ and additional bands at 34,29 , and $24 \mathrm{kDa}$. When cells were treated with $\mathrm{ACTH}$, the intensities of all bands were markedly, but differentially, increased. Quantitative analysis of the IGFBP bands of eight independent experiments indicated that in unstimulated cells, the 39-/44-kDa doublet band accounts for almost half of the detected IGFBP activity ( $46 \pm 5 \%$ ), followed by the $29-\mathrm{kDa}(26 \pm 3 \%)$, the $24-\mathrm{kDa}(15 \pm 2 \%)$, and the 34-kDa $(13 \pm 2 \%)$ bands. A similar binding pattern was observed when bovine serum or cytosol extracts of bovine adrenocortical cells were analyzed by Western ligand blot-

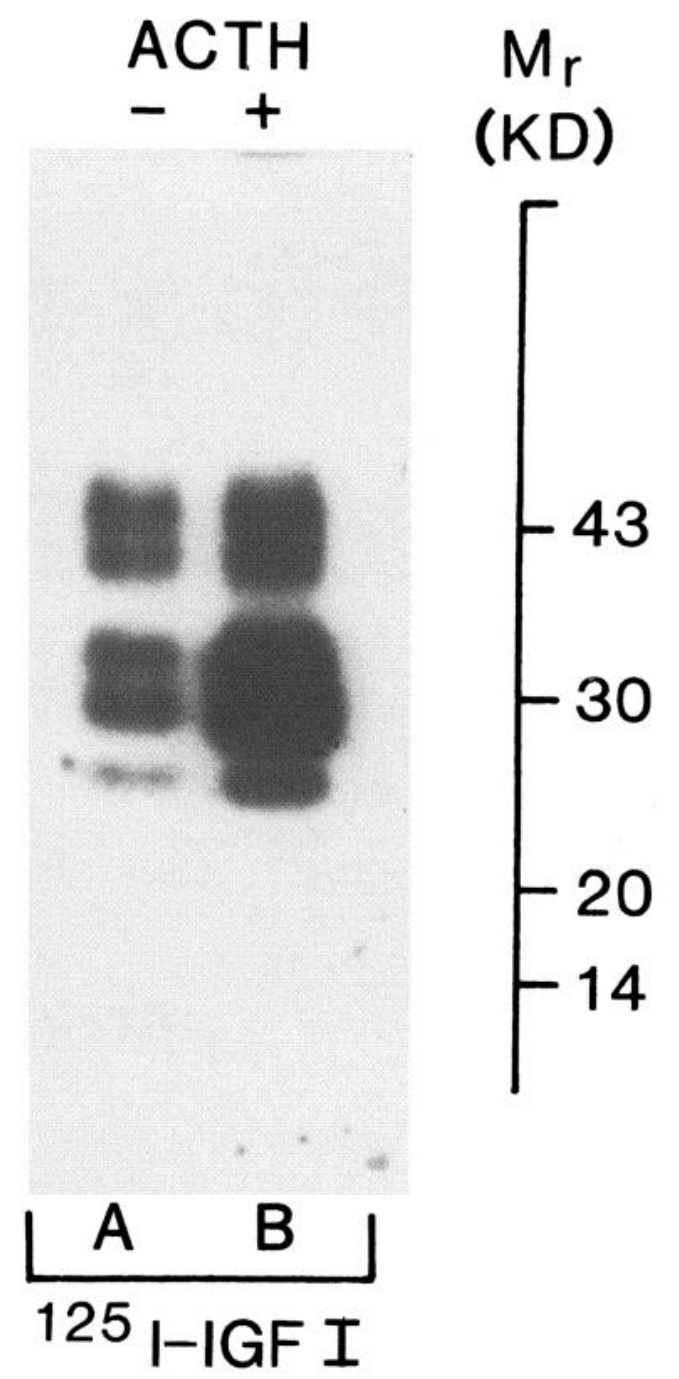

FIG. 6. Western ligand blot of IGFBPs secreted by bovine adrenocortical cells. Cells were incubated with serum-free medium alone (lane A) or ACTH $\left(10^{-8} \mathrm{M}\right.$; lane B) for $48 \mathrm{~h}$. Conditioned medium was concentrated, separated by sodium dodecyl sulfate-polyacrylamide gel electrophoresis under nonreducing conditions, transferred to nitrocellulose, incubated with ${ }^{125}$ I-labeled IGF-I, and autoradiographed. Data are representative of eight independent experiments. 
ting (data not shown). When bovine adrenocortical cells in primary culture were treated with $\mathrm{ACTH}\left(10^{-8} \mathrm{M}\right.$ for $\left.48 \mathrm{~h}\right)$, the abundance of all IGFBPs in the culture medium was up-regulated, on the average, 2.3-fold, except for the 29-kDa band, which was preferentially stimulated 6.8-fold over the unstimulated control group value. The stimulatory effect of ACTH on the abundance of IGFBPs in our cell system was significant greater than the observed unspecific increase in protein concentration in the culture medium after treatment with ACTH (133\% of the control value). No difference in the basal and ACTH-induced binding patterns was observed when $\left[{ }^{125} \mathrm{I}\right] \mathrm{IGF}-\mathrm{II}$ was used as a radioligand.

\section{Discussion}

In the studies reported here, we present an adrenal cell culture system in which IGF-II, through interaction with the IGF-I receptor, is signaling more potently than IGF-I. Our data demonstrate that in primary culture of adult bovine adrenocortical cells, IGF-II stimulates basal as well as ACTHinduced cortisol and cAMP secretion 10 times more potently than IGF-I. This effect is mediated through interaction of both ligands with the IGF-I receptor. The different efficacies of both IGFs might be explained by a modulatory role of IGFBPs, which are produced locally by the adrenocortical cells. Therefore, bovine fasciculata cells provide a readily available cell culture system in which the role of IGFBPs in modulating IGF signaling through the IGF-I receptor can be evaluated.

In the present studies, recombinant human IGF-II at physiological concentrations (34) stimulated basal as well as ACTH-induced cortisol secretion in a dose-dependent way. This effect was significant after $12 \mathrm{~h}$ and reached its maximum after $24 \mathrm{~h}$. Although treatment with IGF-II alone elicited only a moderate 3-fold increase in cortisol output, the effect of IGF-II on AC"IH-induced cortisol secretion (19-fold stimulation) was synergistic, with a 29 -fold increase in basal cortisol secretion. In dose-response experiments, both IGFs at a pharmacological dose (52 nM) stimulated ACTH-induced cortisol secretion to a similar extent, and no additive effect of both ligands was observed. At physiological concentrations, however, the dose-response curve of IGF-II was significantly shifted to the left compared to that of IGF-I. IGF-II was 10 times more effective in increasing $\mathrm{ACTH}$-stimulated cortisol secretion $\left(\mathrm{ED}_{50}=0.9 \mathrm{~nm}\right)$ than IGF-I $\left(\mathrm{ED}_{50}=10 \mathrm{~nm}\right)$. The observed effect of IGF-I on basal and ACTH-induced cortisol and CAMP secretion in adult bovine adrenocortical cells is in accordance to previous reports of an IGF-I-stimulated steroidogenic response in bovine $(15,24)$, ovine $(21)$, and human (22) adrenal cells. In rats, however, an inhibitory effect of IGF-I on ACTH-induced steroidogenesis in isolated adrenal cells has been described (27). The only study on the effect of IGF-II on adrenal hormone secretion reports a stimulatory effect of IGF-II on $\Lambda \mathrm{CTH}$-induced cortisol secretion in human fetal adrenal cells (20). This is in good accordance with our findings in adult bovine adrenocortical cells. Our observation that IGF-II is more potent than IGF-I in stimulating bovine adrenocortical steroidogenesis supports the hypothesis that IGF-II is an important regulator of adrenocortical cell function. A predominant role of IGF-II in the autocrine/ paracrine regulation of adrenal steroidogenesis has been postulated previously from a coordinate expression of IGF-II and steroidogenic enzyme mRNAs in fetal human and ovine adrenal glands $(11,35)$.

As we reported, bovine adrenocortical cells express both lypes of IGF receptors (18). I Iowever, in most cell systems the effects of both IGFs are mediated through interaction with the IGF-I receptor $(2,36)$. As the IGF-I receptor in our cell system exhibits a slightly higher affinity for IGF-I than for IGF-II, with a half-maximal competition for [ $\left.{ }^{125} \mathrm{I}\right] \mathrm{IGF}-\mathrm{I}$ binding by 0.8 and $6.5 \mathrm{~nm}$ unlabeled IGF-I and IGF-II, respectively (18), a stronger biological effect of IGF-I compared to that of IGF-II would have been expected. Therefore, the observed 10 -fold stronger bioactivity of IGF-II compared to that of IGF-I is in contrast to their affinities for the IGF-I receptor. Taking into account that bovine adrenocortical cells contain far more IGF-II/M6P receptors than IGF-I receptors (18), the dose-response experiments do not allow us to assign the effect of IGF-II to a specific IGF receptor. The facts that the maximum responses of $I G F-I$ and IGF-II were the same, and no synergistic effect by the combination of both ligands was observed provide indirect evidence that the stimulatory effect of both IGFs is mediated through the same receptor. Although the type II IGF receptor is abundant in bovine adrenocortical cells, and the concentration of unlabeled IGF-II required to displace $50 \%$ of labeled IGF-II bound to this receptor $(1.8 \mathrm{~nm})$ is similar to the dose of IGF-II necessary for a half-maximal stimulatory effect $(0.9 \mathrm{nM})$, it is unlikely that both ligands mediate their effects through the IGF-II/ $\mathrm{M} 6 \mathrm{P}$ receptor. IGF-I only in micromolar concentrations shows binding to the IGF-II/M6P receptor, and the role of the IGF-II/M6P receptor in IGF signaling remains controversial (7). By treating bovine adrenocortical cells with mutant IGF-II ligands that bind with different affinities to the type I and type II IGF receptor, we confirmed that in these cells the effect of IGF-II is mediated through interaction with the IGF-I receptor, and that IGF-II/M6P receptors are not required for stimulation of cortisol secretion by ICF-II. Thus, [Arg ${ }^{54,55}$ ]IGF-II, which does not bind to the IGF-II/M6P receptor, but shows high affinity for the IGF-I receptor, was equipotent to IGF-II. In contrast, [Leu ${ }^{27}$ ]IGF-II, which has a high affinity for the IGF-II receptor, but exhibits only minimal binding to the IGF-I receptor, was ineffective in stimulating cortisol secretion.

The mechanism by which IGFs increase ACTI I-stimulated steroidogenesis in adrenal cells remains unclear (20). Previous studies show that in bovine adrenocortical cells, IGF-I up-regulates $\mathrm{ACTH}$ receptors, whereas ACTH stimulates the abundance of IGF-I receptors and the secretion of an IGF-Ilike peptide $(12,24,37)$. To further elucidate the mechanism by which IGF-II, through interaction with the IGF-I receptor, modulates the steroidogenic response to $\mathrm{ACTH}$, we measured the concentration of CAMP in the culture medium. As reported previously, the increase in cAMP in the medium of intact adrenocortical cells reflects the intracellular action of adenylate cyclase due to ACTH stimulation (38). In our study we found that IGF-I and, more potently, IGF-II stimulate ACTH-induced CAMP accumulation in the medium of adult bovine adrenocortical cells. 'l'his increase correlates closely with the effects of IGF-I and IGF-II on cortisol secretion in the 
same cells. The facts that the synergistic effect of IGF-II on ACTH-promoted cortisol secretion was paralleled by the accumulation of CAMP, and that IGF-II predominantly stimulates ACTH-induced steroidogenesis, but has only a weak stimulatory effect by itself support the hypothesis that upregulation of the $\Lambda \mathrm{CTH}$ receptor by IGF-II is an important mechanism for the IGF-induced increase in the sensitivity of bovine adrenocortical cells to ACTH.

As the discrepant potency of IGF-I and IGF-II in our cell system might be explained by interaction of these ligands with IGFBPs, we performed incubation experiments with IGF variants exhibiting reduced affinities for IGFBPs. [des ${ }^{1-3}$ ]IGF-I, which exhibits unaltered affinity for the IGF-I receptor, but weak or almost no binding to IGFBPs, showed a significantly stronger stimulatory effect on ACTH-induced cortisol secretion than native IGF-I. In contrast, [des ${ }^{1-6}$ ]IGFII, a truncated form of IGF-II that binds poorly to IGFBPs but also has a reduced affinity for the IGF-I receptor (33), was equipotent to wild-type IGF-II and [des ${ }^{1-3}$ IIGF-I. As the poor binding of [des ${ }^{1}$ JIGF-I to IGFBPs correlates well with its increased bioactivity in our cell system, a preferential interaction of IGF-I with an inhibitory ICFBP would be sufficient to explain the different stimulatory potencies of the two IGFs in bovine adrenocortical cells. This mechanism has been postulated for various other cell systems in which increased bioactivity of [des ${ }^{1-3}$ ]IGF-I compared to that of native IGF-I has been found $(9,33)$. However, IGFBPs are able to modulate the action of IGF through a variety of mechanisms (9), and our results do not conclusively show through which binding protein and what mechanism the modulatory effect of IGFBPs in our cell system is exerted. As many IGFBPs exhibit a greater affinity for IGF-II, it is equally valid to consider the hypothesis that in this cell system, IGF-II may be preferentially bound by IGFBPs that are capable of adhering to the cell surface, thus promoting the interaction of IGF-II with the IGF-I receptor (9).

At least four different IGFBPs are synthesized by bovine adrenal cells, as assayed by Western ligand blotting of conditioned medium. The 39-44 kDa doublet detected in conditioned medium of our cell system corresponds in mol wt to different glycosylation states of IGFBP-3 and was found to be of similar size in control samples of bovine serum. Although the sizes of the 34-, 29-, and 24-kDa bands would be compatible with IGFBP-2, IGFBP-5 or -6 , and IGFBP-4, respectively, the exact identification of the various bands requires further confirmation. A similar binding pattern for IGFBPs has previously been reported for bovine adrenal fasciculata cells (39), cultured bovine fibroblasts (40), and human fetal adrenal cells (41). In contrast to the findings in adult bovine adrenocortical cells, no regulation of IGFBPs by $\mathrm{ACTH}$ has been observed in human fetal adrenal cells, which might be due to developmental or species-specific differences (41). The fact that in adult bovine adrenocortical cells, IGFBPs are differentially up-regulated by treatment with ACTH may contribute to the complex mechanism of homeostasis and modulation of IGF action in the adrenal gland. At the cellular level, both inhibition and stimulation of IGFmediated action by IGFBPs have been reported. However, the precise mechanism by which IGFBP's modulate IGF signaling remains speculative (9).
Our data support the hypothesis that interactions between IGFs and locally produced IGFBPs with the IGF-I receptor play an important role in the regulation of adrenal steroidogenesis. The possible interactions of two related $\mathrm{IGF}$ ligands with two types of IGF receptors and several different IGFBPs in the same cellular environment explain part of the difficulties in understanding the molecular mechanism of IGF signaling. Therefore, bovine adrenocortical cells provide a useful tool to further evaluate the role of IGFBPs in modulating IGF signaling at the cellular level.

\section{Acknowledgments}

The authors thank Dr. Sakano (Daiichi Pharmaceutical Co.) for kindly providing mutant IGF-II ligands, and Barbara Adelmann and Gerald Spöttl for excellent technical assistance.

\section{References}

1. Daughaday WH, Rotwein P 1989 Insulin-like growth factors I and II. Peptide, messenger ribonucleic acid and gene structures, serum and tissue concentrations. Endocr Rev 10:68-91

2. Humbel RE 1990 Insulin-like growth factors I and II. Eur J Biochem 190:445-462

3. LeRoith D, Adamo M, Werner H, Roberts CT 1991 Insulin-like growth factors and their receptors as growth regulators in normal physiology and pathological state. Trends Endocrinol Metab 2: $134-139$

4. Underwood LE, D'Ercole AJ, Clemmons DR, Van Wyk JJ 1986 Paracrine functions of somatomedins. Clin Endocrinol Metab 15: $59-57$

5. Kiess W, Blickenstaff GD, Sklar MM, Thomas CL, Nissley SP, Sahagian GG 1988 Biochemical evidence that the type II insulin-like growth factor receptor is identical to the cation-independent mannose 6-phosphate receptor. J Biol Chem 263:9339-9344

6. Rechler MM, Nissley SP 1990 Insulin-like growth factors. In: Sporn MS, Roberts AB (eds) Handbook of Experimental Pharmacology. Springer Verlag, Heidelberg and New York, pp 263-367

7. Roth RA 1988 Structure of the receptor for insulin-like growth factor II: the puzzle amplified. Science 239:1269-1271

8. Clemmons DR 1990 Insulin like growth factor binding proteins. Trends Endocrinol Metab 1:412-417

9. Rechler MM 1995 Non-receptor-binding proteins for Insulin-like growth factors and other cytokines: modulators of peptide action. In: Weintraub BD (ed) Molecular Enducrinology: Basic Concepts and Clinical Correlations. Raven Press, New York, pp 155-180

10. Han VKM, Lund PK, Lee DC, D'Ércole AJ 1988 Expression of somatomedin/insulin-like growth factor messenger RNAs in the human fetus: identification, charaterization and tissue distribution. J Clin Endocrinol Metab 66:422-429

11. Han VKM, Lu F, Bassett N, Yang KP, Delhanty PJD, Challis JRG 1992 Insulin-like growth factor-II (IGF-II) messenger ribonucleic acid is expressed in steroidogenic cells of the developing ovine adrenal gland: evidence of an autocrine/paracrine role for IGF-II Endocrinology 131:3100-3109

12. Penhoat A, Naville D, Jaillard C, Chatelain PG, Saez JM 1989 Hormonal regulation of insulin-like growth factor I secretion by bovine adrenal cells. J Biol Chem 264:6858-6862

13. Townsend SF, Dallman MF, Miller WL 1990 Rat insulin-like growth factor-I and-II mRNAs are unchanged during compensatory adrenal growth but decrease during ACTH-induced adrenal growth. J Biol Chem 256:22117-22122

14. Arafah BM 1991 Insulin-like growth factor-I receptors in the rat adrenal. J Lab Clin Med 00:531-537

15. Penhoat A, Chatelain PG, Jaillard C, Saez JM 1988 Characterization of insulin-like growth factor I and insulin receptors on cultured bovine adrenal fasciculata cells: role of these peptides on adrenal cell function. Endocrinology 122:2518-2526

16. Pillion DJ, Yang M, Grizzle WE 1988 Distribution of receptors for 
insulin-like growth factor-I (somatomedin C) in the adrenal gland. Biochem Biophys Res Commun 154:138-145

17. Shigematsu K, Niwa M, Kurihara M, Yamashita K, Kawai K, Tsuchiyama H 1989 Receptor autoradiographic localization of insulin-like growth factor-I (IGF-I) binding sites in human fetal and adult adrenal glands. Life Sci 45:383-389

18. Weber MM, Kiess W, Beikler T, Simmler $\mathbf{P}$, Reichel $\mathbf{M}$, Adelmann B, Kessler U, Engelhardt D 1994 Identification and characterization of insulin-like growth factor I (IGF-I) and IGF-II/mannose-6-phosphate (IGF-II/M6P) receptors in bovine adrenal cells. Eur J Endocrinol 130:265-270

19. Mesiano S, Mellon SH, Jaffe RB 1993 Mitogenic action, regulation, and localization of insulin-like growth factors in the human fetal adrenal gland. J Clin Endocrinol Metab 76:968-975

20. Mesiano S, Jaffe RB 1993 Interaction of insulin-like growth factor-II and estradiol directs steroidogenesis in the human fetal adrenal toward dehydroepiandrosterone sulfate production. J Clin Endocrinol Metab 77:754 758

21. Naaman E, Chatelain P, Saez JM, Durand P 1989 In vitro effect of insulin and insulin-like growth factor-I on cell multiplication and adrenocorticotropin responsiveness of fetal adrenal cells. Biol Reprod 40:570-577

22. Pham-Huu-Trung MT, Villette JM, Bogyo A, Duclos JM, Fiet J, Binoux M 1991 Effects of insulin-like growth factor-I (IGF-I) on enzymatic activity in human adrenocortical cells. Interactions with ACTH. J Steroid Biochem Mol Biol 39:903-909

23. Naseeruddin SA, Hornsby PJ 1990 Regulation of $11 \beta$-17 $\alpha$-hydroxylases in cultured bovine adrenocortical cells: $3^{\prime}, 5^{\prime}$-cyclic adenosine monophosphate, insulin-like growth factor-I, and activators of protein kinase C. Endocrinology 127:1673-1681

24. Penhoat A, Jaillard C, Saez JM 1989 Synergistic effects of corticotropin and insulin-like growth factor I on corticotropin receptors and corticotropin responsiveness in cultured bovine adrenocortical cells. Biochem Biophys Res Commun 165:355-359

25. Pham-Huu-Trung MT, Binoux M 1990 Insulin-like growth factor-I (IGF-I) induces cortisol production in bovine adrenocortical cells in primary culture. J Steroid Biochem 36:583-588

26. Simmler P, Weber MM, Engelhardt D 1993 Effect of IGF-I on cortisol biosynthesis in primary bovine adrenocortical cells. Exp Clin Endocrinol [Suppl 1] 101:100 (Abstract)

27. Fujii H, Iida S, Tsugawa M, Gomi M, Moriwaki K, Tarui S 1990 Inhibitory effect of somatomedin $\mathrm{C}$ /insulin-like growth factor I on adrenocorticotropin- or forskolin-induced steroidogenesis in isolated rat adrenocortical cells. Endocrinology 126:26-30

28. Dijk van JP, Tanswell AK, Challis JRG 1988 Insulin-like growth factor (IGF)-II and insulin, but not IGF-I are mitogenic for fetal rat adrenal cells in vitro. J Endocrinol 119:509-516
29. Ilvesmäki V, Kahri AI, Miettinen PJ, Voutilainen R 1993 Insulinlike growth factors (IGFs) and their receptors in adrenal tumors: high IGF-II expression in functional adrenocortical carcinomas. J Clin Endocrinol Metab 77:852-858

30. Goodyer CG, Torday JS, Smith BT, Giroud CJP 1976 Preliminary observations of bovine adrenal fasciculata-reticularis cells in monolyer culture: steroidogenesis, effect of ACTH and cyclic AMP. Acta Endocrinol (Copenh) 83:373-385

31. Stalla GK, Giesemann G, Müller OA, Wood WG, Scriba PC 1981 The development of a direct homologous radioimmunoassay for serum cortisol. J Clin Chem Clin Biochem 19:427-434

32. Sakano K, Enjoh T, Numata F, Fujiwara H, Marumoto $Y$, Higashihashi N, Sato Y, Perdue JF, Fujita-Yamaguchi Y 1991 The design, expression and characterization of human insulin-like growth factor II (IGF-II) mutants specific for either the IGF-II/cation-independent mannose-6-phosphate receptor or IGF-I receptor. J Biol Chem 266: 20626-20635

33. Francis GL, Alpin SE, Milner SJ, McNeil KA, Ballard JF, Wallace JC 1993 Insulin-like growth factor (IGF)-II binding to IGF-binding proteins and IGF receptors is modified by deletion of the N-terminal hexapeptide or substitution of arginine for glutamate-6 in IGF-II. Biochem J 293:713-719

34. Honegger A, Humbel RE 1986 Insulin-like growth factors I and II in fetal and adult bovine serum. J Biol Chem 261:569-575

35. Voutilainen R, Miller WL 1987 Coordinate tropic hormone regulation of mRNAs for insulin-like growth factor II and the cholesterol side-chain-cleavage enzyyme, P450ssc, in human steroidogenic tissues. Proc Natl Acad Sci USA 84:1590-1594

36. Weber MM, Melmed S, Rosenbloom J, Yamasaki H, Prager D 1992 Rat somatotroph insulin-like growth factor-II (IGF-II) signaling: role of the IGF-I receptor. Endocrinology 131:2147-2153

37. Louveau I, Penhoat A, Saez JM 1989 Regulation of IGF-I receptors by corticotropin and angiotensin-II in cultured bovine adrenocortical cells. Biochem Biophys Res Commun 163:32-36

38. Schimmer BP, Schulz P 1985 The roles of CAMP and CAMP-dependent protein kinase in forskolin's actions in $\mathrm{Y} 1$ adrenocortical tumor cells. Endocr Res 11:199-209

39. Penhoat A, Leduque P, Jaillard C, Chatelain PG, Dubois PM, Saez JM 1991 ACTH and angiotensin II regulation of insulin-like growth factor-I and its binding proteins in cultured bovine adrenal cells. J Mol Endocrinol 7:223-232

40. Conover CA 1990 Regulation of insulin-like growth factor (IGF) binding protein synthesis by insulin and IGF-I in cultured bovine fibroblasts. Endocrinology 126:3139-3145

41. Ilvesmäki V, Blum WF, Voutilainen R 1993 Insulin-like growth factor binding proteins in the human adrenal gland. Mol Cell Endocrinol 97:71-79 